\title{
The role of thermography in ophthalmology
}

\section{Anna Modrzejewska}

I Chair and Clinic of Ophthalmology, Pomeranian Medical University in Szczecin Head: Prof. Anna Machalińska, MD, PhD

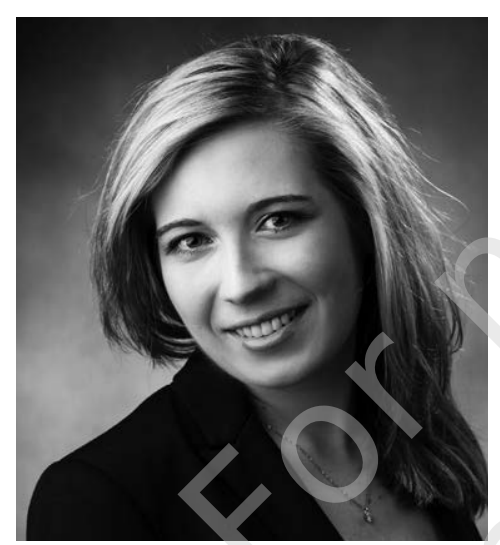

H I G H L I G H T S

Thermography is used for the evaluation of the ocular surface in dry eye syndrome, severity of inflammation, detection of intraocular tumours or retinal ischaemia.

\section{ABSTRACT}

Thermography is used to assess the extent and intensity of local hyperaemia and tissue metabolism based on the emitted radiation in the infrared range. In ophthalmology, it is used for the diagnosis of ocular inflammatory conditions. Increased ocular surface temperature is observed in tumours such as melanoma and uveal naevus. Reduced temperature as a result of blood flow disorders is detected in patients with vascular occlusion, glaucoma, diabetic retinopathy or AMD. Lower emission of infrared radiation on the ocular surface was observed in dry eye syndrome due to tear film instability and faster tear evaporation. Thermography is a non-invasive, fast and objective technique, and in the future it may complement the diagnostic process of many ophthalmic diseases.

Key words: thermography, thermal imaging camera, ophthalmology, ocular surface temperature, infrared, thermal emission 


\section{INTRODUCTION}

Infrared radiation is a type of electromagnetic radiation with a wavelength in the range of $0.78-1000 \mu \mathrm{m}$, which was discovered in 1800 by William Herschel [1]. Every object and every living organism emits and reflects infrared radiation, which can be recorded by thermal imaging cameras as a temperature map or thermogram. Images are usually visualized using the rainbow colour order, where white or red indicates higher, and blue or green indicates lower temperatures. The analysed object is compared to the perfect black body (with a coefficient equal to 1.0), which absorbs $100 \%$ of radiation, and to the perfect white body that reflects $100 \%$ of radiation [2]. Measuring devices have been improved for more than 100 years since the first thermograms were acquired. Thermography in medicine was first used at the end of the $19^{\text {th }}$ century for the early detection of breast cancer [1]. A thermal imaging camera visualized the area of the skin covering the tumour as a warmer area than that of normal tissue, so it was possible to determine the margin of the affected tissue [3]. Further studies revealed that higher temperature was positively correlated with greater blood flow and more severe inflammation in the region of interest. Increased metabolic activity of tissues is associated with the accumulation of carbon dioxide, prostaglandins and other proinflammatory factors, which leads to vasodilatation and hyperaemia, and thus to an exothermic reaction and the release of heat to the environment $[4,5]$. The increase in local temperature can be quantified with a thermal imaging camera [6].

\section{EXAMINATION TECHNIQUE}

In recent years, significant progress has been made to improve the standardization of this diagnostic technique and refine clinical protocols. The accuracy of thermal imaging depends on a number of factors, and clinicians have to be aware of them to correctly analyze the images. Researchers have emphasized the influence of different environmental conditions, posture, as well as the angle and distance from the camera during examination on the repeatability of measurements. Conditions in the room, i.e. air temperature, air currents and humidity may significantly affect measurements taken with the thermographic camera. It is recommended that the images should be acquired after resting for 15 minutes in the examination room, perpendicularly to the examined area, and at a distance of $1 \mathrm{~m}$ from the camera $[7,8]$. The influence of variability in the same patient on the acquired measurements is eliminated by comparing symmetrical areas of the body surface. The patient's age and appearance, e.g. body hair, amount of subcutaneous tissue or skin changes may also disturb local heat transfer, which should be taken into account in thermographic analysis [9-11].
The ocular surface, however, is unaffected by the above-mentioned confounders. No differences in temperature were found between male and female subjects. However, the ocular surface temperature decreases with the time point after blinking and with the age of the studied patients [12,13]. The ocular surface temperature decreases by $0.01-0.02^{\circ} \mathrm{C}$ per year throughout life, and the rate of change increases after middle age [14]. The mean ocular surface temperature at the corneal centre is $34.3^{\circ} \mathrm{C} \pm 0.7$ and it does not depend on corneal thickness or the depth of the anterior chamber [15]. The highest temperatures were measured in the nasal field of the conjunctiva and around the corneal limbus, and they were about $0.45-1^{\circ} \mathrm{C}$ higher than those measured in the centre of the eye $[16,17]$. Lower temperatures at the corneal centre are probably associated with the absence of blood vessels and the presence of a thin layer of the tear film in this area, which is prone to faster evaporation [18-20].

\section{OCULAR APPLICATIONS OF THERMOGRAPHY}

There are a number of papers reporting potential applications of a thermal imaging camera in the diagnosis of ocular diseases. Most studies on the use of thermography in ophthalmology concern the diagnosis of dry eye syndrome (fig. 1). Tear film abnormalities result in low thermal emission and reduced ocular surface temperature [21]. The degree of temperature reduction correlates with the results of the Schirmer test, the tear meniscus height (TMH) and the tear breakup time (TBUT) [22, 23]. The increased instability and evaporation of the tear film is particularly common in the elderly. Many researchers have found a negative correlation between the patient's age and the ocular surface temperature, which may result in symptoms of dry eye that worsen with age $[14,18]$.

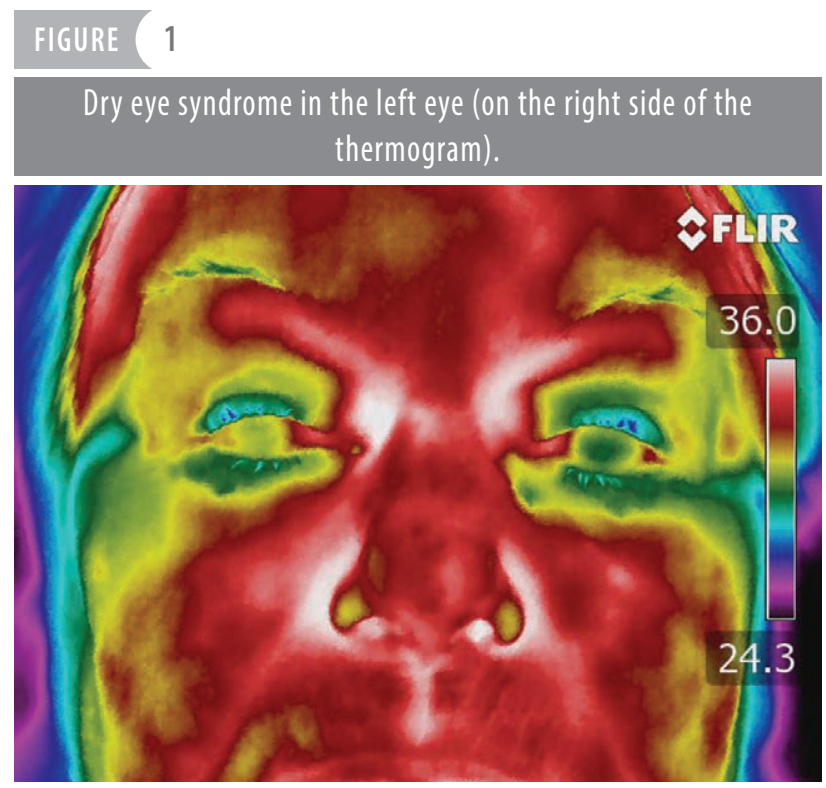


Studies on the use of thermography in cataract surgery began in 1994. Rise in corneal temperature after extracapsular cataract extraction [24] and corneal burns induced by phacoemulsification [25] have been reported. To assess the effect of phacoemulsification on the ocular surface temperature, researchers took intraoperative measurements on the corneal surface and in the anterior chamber [26]. The highest temperature measured at the corneal surface was $44.9^{\circ} \mathrm{C}$. Studies have revealed that thermography may be useful in the operating room to assess the corneal surface temperature during cataract surgery performed with different techniques and phacoemulsification ultrasonic tips $[27,28]$. For example, Giannaccare et al. used a thermal imaging camera to examine patients on days 7 and 28 after cataract phacoemulsification, and compared to preoperative measurements they found cooling in the central cornea, but heating in the temporal limbus. Measured temperature was inversely related to the OSDI (Ocular Surface Disease Index) and directly related to TBUT. Warming in the temporal region was associated with aseptic inflammation, which developed in response to perioperative tissue injury [29]. This observation was also confirmed by Shih et al. Temperature in this area normalized one month after surgery [30]. Many studies have indicated an increased incidence of dry eye syndrome after cataract surgery. This procedure involves incision of the cornea and disruption of the tear film, which may aggravate previously existing symptoms. A decrease in the tear meniscus height, TBUT elongation, squamous metaplasia and decreased corneal sensation after surgery have also been reported [31,32]. Modrzejewska et al. used a thermal imaging camera to measure temperature in the ocular region in patients one month after cataract surgery, and compared the obtained values to those measured one day before the surgery. The reported mean ocular surface temperature was lowest on day 14 after surgery, then increased and normalized on day 28 [33] (fig. 2).
Microbiological assay is the gold standard in the assessment of the aetiology of ocular inflammation but it is not used routinely $[34,35]$. The diagnosis is usually based on the examination of the eye using a slit lamp and the assessment of symptoms reported by the patient [36-38]. Both tests are subjective. For many years clinicians have been trying to find objective and quantitative techniques for the assessment of ocular inflammation. Studies have demonstrated that in scleritis, uveitis or keratitis, the ocular surface appears warmer on thermograms compared to normal tissues. The ocular surface temperature in patients with corneal bacterial ulcer was $0.8^{\circ} \mathrm{C}$ higher than in the normal eye $[39,40]$. Modrzejewska et al. measured ocular temperature in patients with various inflammatory conditions of the eye. An increase in the mean temperature at the central point of the cornea, the ocular surface and in the orbital cavity was found in patients with conjunctivitis, keratitis, anterior uveitis and endophthalmitis (fig. 3, 4). The greatest difference in temperature between the affected and normal eyes was found for endophthalmitis $\left(1.23^{\circ} \mathrm{C}\right.$ higher compared to temperature measured at the central point of the cornea and on the ocular surface). Endophthalmitis is characterized by significant damage to the ocular membranes and increased catabolism, and thus a strong exothermic reaction. The lowest gradient was found in keratitis $\left(0.11^{\circ} \mathrm{C}\right.$ at the central point of the cornea and $0.19^{\circ} \mathrm{C}$ on the ocular surface). For all inflammatory conditions temperature measured at the corneal centre was lower than the mean ocular surface temperature: conjunctivitis $\left(34.72^{\circ} \mathrm{C}\right.$ vs. $\left.35.47^{\circ} \mathrm{C}\right)$, keratitis $\left(34.19^{\circ} \mathrm{C}\right.$ vs. $\left.34.92^{\circ} \mathrm{C}\right)$, uveitis $\left(34.40^{\circ} \mathrm{C}\right.$ vs. $\left.35.20^{\circ} \mathrm{C}\right)$, and endophthalmitis $\left(35.27^{\circ} \mathrm{C}\right.$ vs. $\left.35.80^{\circ} \mathrm{C}\right)$. This phenomenon can be explained by the previously described morphological features of the cornea. If corneal structures are not translucent, potential endophthalmitis and its advancement are assessed by ultrasonography, which is a subjective test that depends on the quality of equipment and the examination technique. It was concluded that the thermographic examination may in this case be used as an additional diagnostic tool [41].

\section{FIGURE ( 2}

A thermographic image of a patient's face 1 day before $(A)$ and $1(B), 14(C), 28$ (D) days after cataract surgery of the right eye (on the left side of the thermogram).

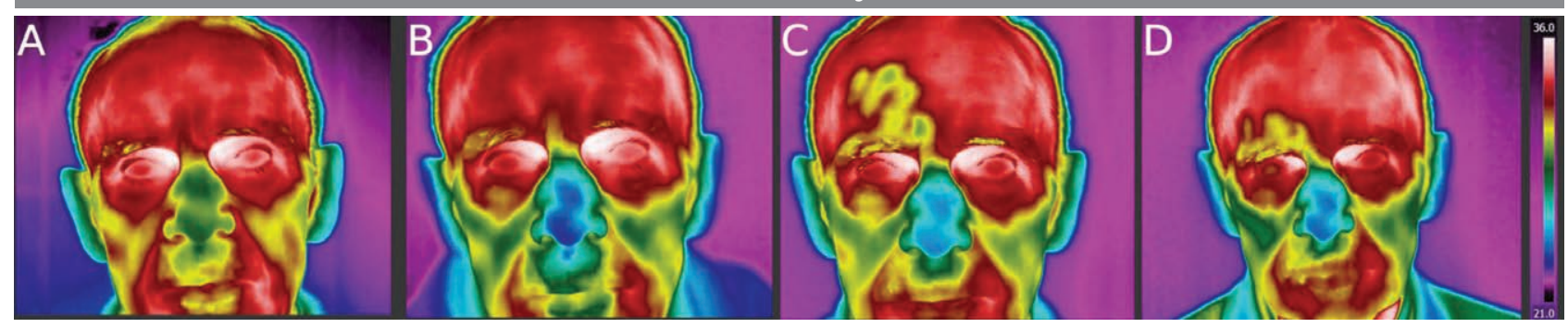




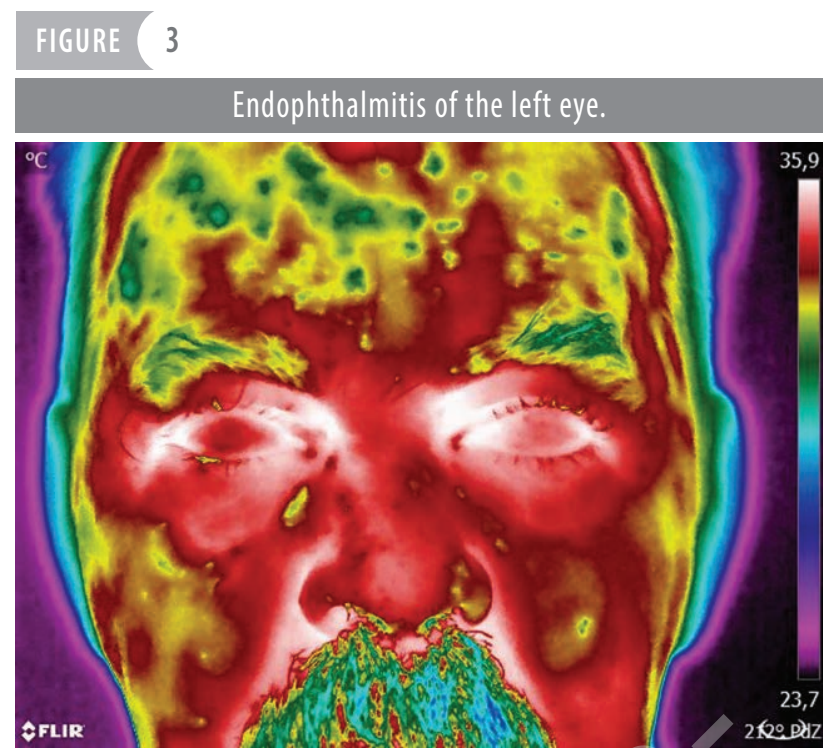

\section{FIGURE $(4$}

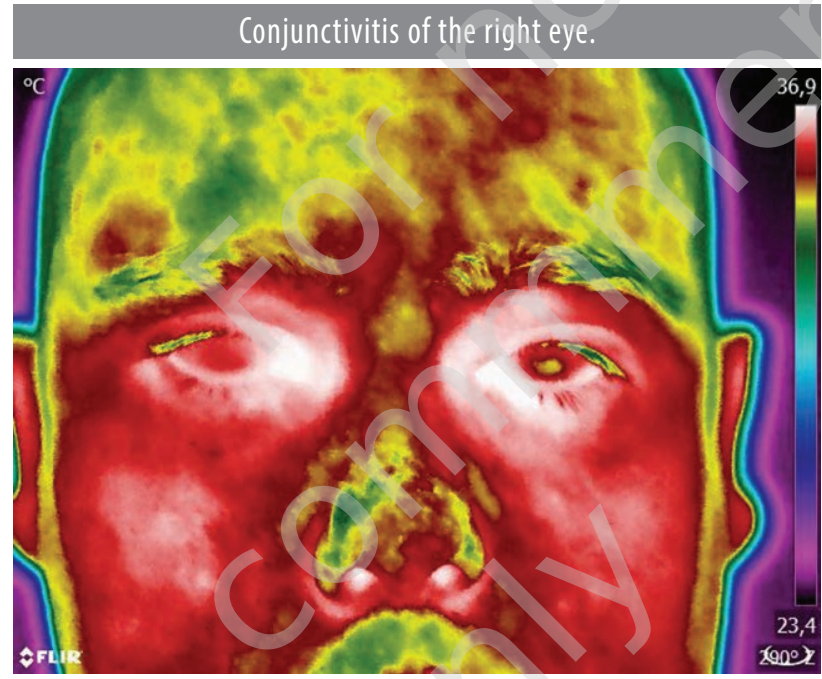

In the case of intraocular tumours, diagnostic difficulties are caused by amelanotic changes and those accompanied by retinal detachment, or the lack of insight into the fundus caused by corneal opacity, narrow pupil or vitreous haemorrhage. The diagnosis and qualification for treatment largely relies on the experience of the clinician analysing the results of additional tests, such as type A or B ultrasonography, Doppler ultrasound, fluorescein angiography or optical coherence tomography. Histopathological examinations prior to eye removal surgery are extremely rare [42]. In 1971, Kruszewski reported that ocular tumours such as melanoma or uveal naevus are visualized in thermography as hot regions [43]. Wittig et al. also noted warming of the ocular surface in melanoma of the conjunctiva and uvea [44]. According to researchers, melanomas are malig- nant cancers with significant thermal activity, which results from abnormal vascularisation of the tumour mass [45]. This hypothesis has been confirmed in other studies revealing that uveal melanoma is characterized by a greater mean maximum blood flow in the central retinal artery, in the posterior ciliary arteries, and total choroidal flow measured by Doppler ultrasound compared to normal eyes $[46,47]$. The role of the immune response and metabolic activity of melanomas was also discussed [48]. These tumours secrete pro-inflammatory and pro-angiogenic cytokines, causing chronic tissue inflammation that promotes tumour growth [49-51]. The thermal imaging camera can detect areas with increased metabolism and blood flow as warmer regions. Modrzejewska et al. found that eyes with uveal melanoma and retinal capillary hemangioblastoma had higher mean temperatures measured at the corneal centre, ocular surface and orbital cavity compared to the patient's other healthy eye (fig. 5).

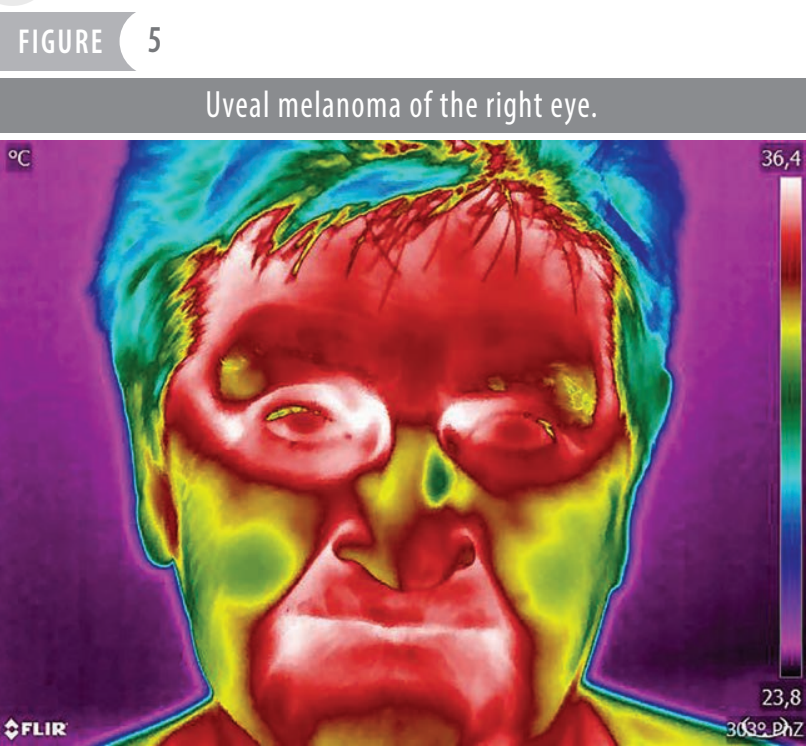

Ocular temperature was higher in the group of patients with uveal melanoma after unsuccessful brachytherapy compared to patients with tumour regression [52] (fig. 6). It is believed that this may indicate positive changes in the tumour area, i.e. vascular occlusion, ischaemia and scarring of the retina [53]. Mean temperature was also lower in eyes with a focal metastasis to the uvea compared to unaffected eyes [52] (fig. 7).

According to Konstantinidis et al., metastatic tumours are poorly vascularised and use the blood supply existing in the local tissue. Moreover, some metastatic tumours may be vascular with extensive necrotic foci [54], which may be responsible for their lower temperature. 


\section{FIGURE $(6$}

A. Uveal melanoma in the left eye after unsuccessful brachytherapy. B. Uveal melanoma in the left eye after successful brachytherapy.

\section{A}

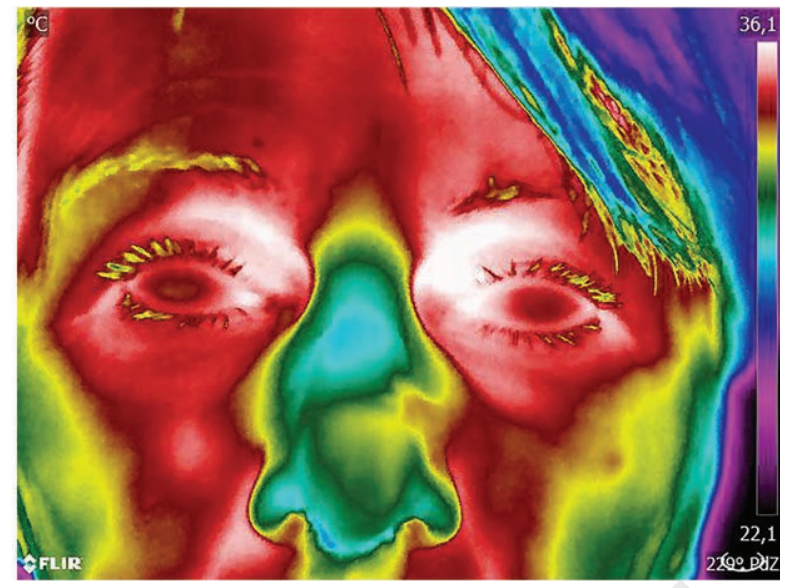

B

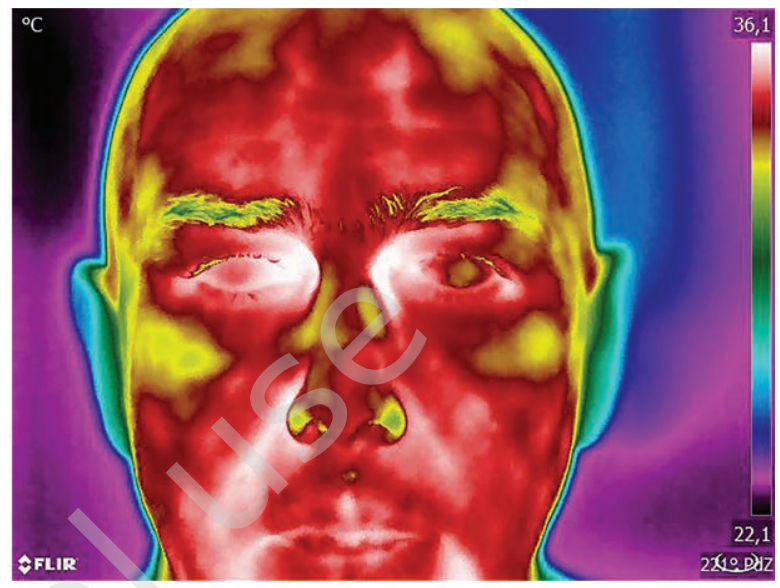

FIGURE ( 7

A. Focal metastasis to the uvea in the left eye. B. Retinal capillary hemangioblastoma in the right eye.

A

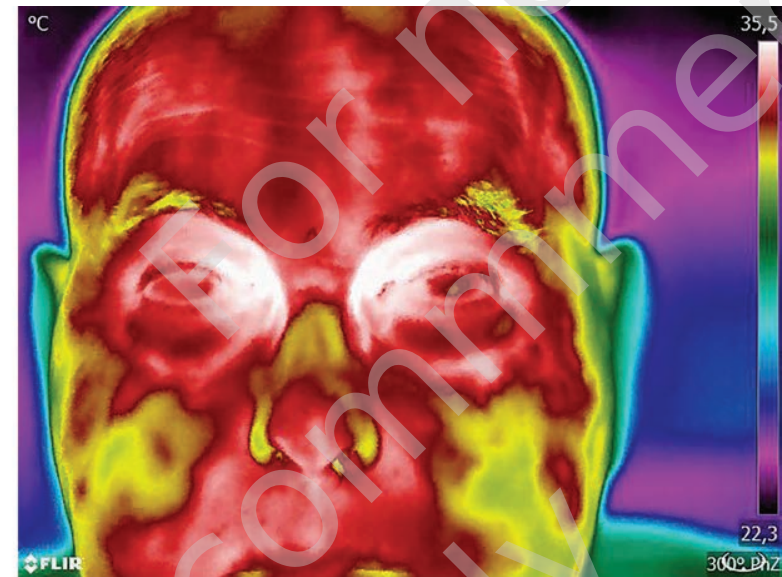

Other studies on the use of thermography in ophthalmology indicate the potential applicability of this method for the detection of occlusion in the central retinal vein. Ocular surface temperature in eyes with central retinal vein occlusion, especially those with ischaemic CRVO, was lower than in unaffected eyes [55].

Thermography showed a lower temperature in eyes with nonproliferative and proliferative diabetic retinopathy and in dry and wet AMD (age-related macular degeneration) compared to eyes without these pathologies [56, 57]. This highlights the role of ischaemia in the pathogenesis of these ophthalmic diseases.

The thermographic camera was also used for the monitoring of the filtering bleb function after glaucoma surgery. A greater temperature gradient was found between a properly functioning bleb and the surrounding conjunctiva compared to the bleb in the eyes with a higher postoperative intraocular pressure [58].
B

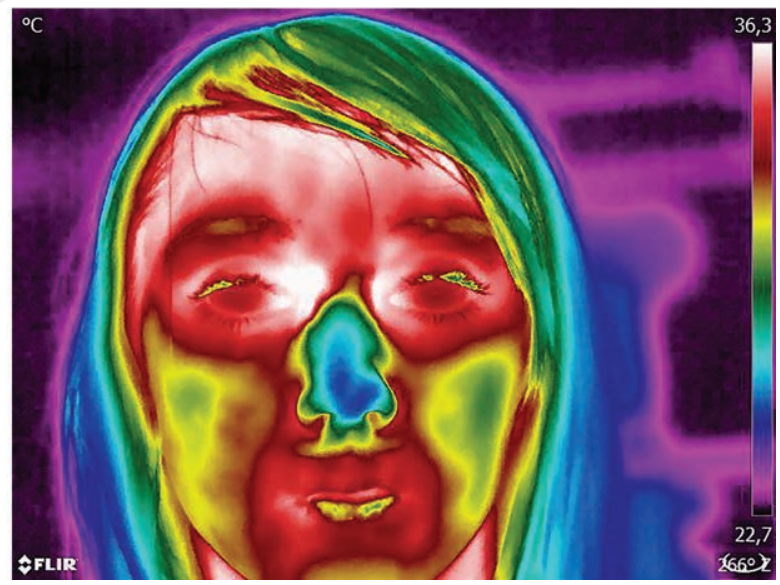

\section{CONCLUSION}

Ocular thermography is a fast, non-invasive and safe procedure that shows real-time temperature distribution on the ocular surface. Because it provides objective and quantitative data, it can be used as a complementary diagnostic tool for the differentiation of ophthalmic diseases or evaluation of treatment outcomes. As in many imaging techniques, computerization and the development of telemedicine have significantly improved the availability and ease of use of thermal imaging cameras. Compact thermal imaging cameras that can be connected to a smartphone via a USB port are popular for industrial applications. Currently, images of the eye fundus can be acquired using a smartphone application or a portable fundus camera in many physicians' offices and opticians worldwide. Dedicated advanced software is used to analyse images for any abnormalities and, if necessary, results are reported to the ophthalmologist. 
Apparently, future advances in ophthalmology are associated with the further miniaturization of measuring devices, the development of telemedicine, and greater availability of specialist diagnostic procedures, including thermography.

Figures: from the author's own materials.

\author{
CORRESPONDENCE \\ Anna Modrzejewska, MD, PhD \\ I Chair and Clinic of Ophthalmology, \\ Pomeranian Medical University in Szczecin \\ 70-111 Szczecin, al. Powstańców Wielkopolskich 72 \\ e-mail:ania_modrzej@o2.pl
}

ORCID

Anna Modrzejewska - ID - http://orcid.org/0000-0002-0393-1041

\section{References}

1. Ring EFJ. The historical development of thermometry and thermal imaging in medicine. J Med Eng Technol. 2006; 30(4): 192-8. http:// doi.org/10.1080/03091900600711332.

2. Tsai SR, Hamblin MR. Biological effects and medical applications of infrared radiation. J Photochem Photobiol B. $2017 ; 170: 197-207$. http://doi.org/10.1016/j.jphotobiol.2017.04.014.

3. Zadeh HG, Haddadnia J, Ahmadinejad N et al. Assessing the Potential of Thermal Imaging in Recognition of Breast Cancer. BreastCare. 2015; 16(18): 8619-23. http://doi.org/10.7314/apjcp.2015.16.18.8619.

4. Mosier DA. Chapter 2 - Vascular Disorders and Thrombosis. Pathologic Basis of Veterinary Disease (Sixth Edition) 2017: 44-72.

5. Vadas P, Wasi S, Movat HZ et al. Extracellular phospholipase A2 mediates inflammatory hyperaemia. Nature. 1981; 15-21; 293(5833): 583-5. http://doi.org/10.1038/293583a0.

6. Jiang LJ, Ng EYK, Yeo ACB et al. A perspective on medical infrared imaging. J Med Eng Technol. 2005; 29(6):257-67. http://doi.org/10.1080/ 03091900512331333158.

7. Ring EFJ, Ammer K. Infrared thermal imaging in medicine. Physiol Meas. 2012; 33(3): 33-46. http://doi.org/10.1088/0967-3334/33/3/R33.

8. Tattersall GJ. Infrared thermography: A non-invasive window into thermal physiology. Comp Biochem Physiol A Mol Integr Physiol. 2016; 202: 78-98. http://doi.org/10.1016/j.cbpa.2016.02.022.

9. Aliò J, Padron M. Influence of age on the temperature of the anterior segment of the eye. Measurements by infrared thermometry. Ophthalmic Res. 1982; 14(3): 153-9. http://doi.org/10.1159/000265187.

10. Bauer J, Dereń E. Standaryzacja badań termograficznych w medycynie i fizykoterapii. Inżynieria Biomedyczna. 2014; $20(1): 11$.

11. Freeman RD, Fatt I. Environmental influences on ocular temperature. Invest Ophthalmol. 1973; 12(8): 596-602.

12. Shah AM, Galor A. Impact of Ocular Surface Temperature on Tear Characteristics: Current Insights. Clin Optom (Auckl). 2021; 13: 51-62. http://doi.org/10.2147/OPTO.S281601.

13. Sniegowski M, Erlanger M, Velez-Montoya R et al. Difference in ocular surface temperature by infrared thermography in phakic and pseudophakic patients. Clin Ophthalmol. 2015; 9: 461-6. http://doi.org/10.2147/OPTH.S69670.

14. Morgan PB, Soh MP, Efron N. Corneal surface temperature decreases with age. Cont Lens Anterior Eye. 1999; 22(1): 11-3. http://doi. org/10.1016/s1367-0484(99)80025-3.

15. Pattmöller J, Wang J, Zemova E et al. Correlation of corneal thickness, endothelial cell density and anterior chamber depth with ocular surface temperature in normal subjects. Z Med Phys. 2015; 25(3): 243-50. http://doi.org/10.1016/j.zemedi.2014.09.008.

16. Acharya UR, Ng EY, Yee GC et al. Analysis of normal human eye with different age groups using infrared images. J Med Syst. 2009; 33(3): 207-13. http://doi.org/10.1007/s10916-008-9181-5.

17. Alio J, Padron M. Normal variations in the thermographic pattern of the orbito-ocular region. Diagn Imaging. 1982; 51 (2): $93-8$.

18. Kamao T, Yamaguchi M, Kawasaki S et al. Screening for dry eye with newly developed ocular surface thermographer. Am J Ophthalmol. 2011; 151: 782-91. http://doi.org/10.1016/j.ajo.2010.10.033.

19. Versura P, Giannaccare G, Fresina $M$ et al. Subjective discomfort symptoms are related to low corneal temperature in patients with evaporative dry eye. Cornea. 2015; 34: 1079-85. http://doi.org/10.1097/ICO.0000000000000512.

20. Craig JP, Singh I, Tomlinson A et al. The role of physiology in ocular surface temperature. Eye. 2000; 14: 635-41. http://doi.org/10.1038/ eye.2000.156. 
21. Żelichowska B, Różycki R, Tłustochowicz M. Przydatność termografii w diagnostyce zespołu suchego oka. Klin Oczna 2005 ; 7-9.

22. Azharuddin M, Bera SK, Datta $\mathrm{H}$ et al. Thermal fluctuation based study of aqueous deficient dry eyes by non-invasive thermal imaging. Exp Eye Res. 2014; 120: 97-102. http://doi.org/10.1016/j.exer.2014.01.007.

23. Su TY, Ho WT, Lu CY et al. Correlations among ocular surface temperature difference value, the tear meniscus height, Schirmer's test and fluorescein tear film break up time. Br J Ophthalmol. 2015; 99(4): 482-7. http://doi.org/10.1136/bjophthalmol-2014-305183.

24. Fujishima H, Toda I, Yagi Y et al. Quantitative evaluation of postsurgical inflammation by infrared radiation thermometer and laser flare-cell meter. J Cataract Refract Surg. 1994; 20(4): 451-4. http://doi.org/10.1016/s0886-3350(13)80183-6.

25. Khodabakhsh AJ, Zaidman G, Tabin G. Corneal surgery for severe phacoemulsification burns. Ophthalmology. 2004; 111 (2): $332-4$. http://doi.org/10.1016/j.ophtha.2003.06.004.

26. Donnenfeld ED, Olson RJ, Solomon R et al. Efficacy and wound temperature gradient of WhiteStar phacoemulsification through a 1.2 mm incision. J Cataract Refract Surg. 2003; 29(6): 1097-100. http://doi.org/10.1016/s0886-3350(02)01917-x.

27. Bissen-Miyajima H, Shimmura S, Tsubota K. Thermal effect on corneal incisions with different phacoemulsification ultrasonic tips. J Cataract Refract Surg. 1999; 25(1): 60-4. http://doi.org/10.1016/s0886-3350(99)80012-1.

28. Corvi A, Innocenti B, Mencucci R. Thermography used for analysis and comparison of different cataract surgery procedures based on phacoemulsification. Physiol Meas. 2006; 27(4): 371-84. http://doi.org/10.1088/0967-3334/27/4/004.

29. Giannaccare G, Fresina M, Agnifili L et al. Ocular-surface temperature modification by cataract surgery. J Cataract Refract Surg. 2016; 42(7): 983-9. http://doi.org/10.1016/j.jcrs.2016.04.023.

30. Shih SR, Li HY, Hsiao YL, et al. The application of temperature measurement of the eyes by digital infrared thermal imaging as a prognostic factor of methylprednisolone pulse therapy for Graves' ophthalmopathy. Acta Ophthalmol. 2010; 88(5): 154-9. http://doi. org/10.1111/j.1755-3768.2010.01941.x.

31. Li X-M, Hu L, Hu J et al. Investigation of dry eye disease and analysis of the pathogenic factors in patients after cataract surgery. Cornea. 2007; 26: 16-20. http://doi.org/10.1097/ICO.0b013e31812f67ca.

32. Khanal S, Tomlinson A, Esakowitz $L$ et al. Changes in corneal sensitivity and tear physiology after phacoemulsification. Ophthalmic Physiol. 2008; 28: 127-34. http://doi.org/10.1111/j.1475-1313.2008.00539.x.

33. Modrzejewska A, Cieszyński $Ł$, Zaborski D et al. Infrared thermography for the analysis of ocular surface temperature after phacoemulsification. Arq Bras Oftalmol. 2020; 83(3): 202-8. http://doi.org/10.5935/0004-2749.20200035.

34. Jones DB. Decision-making in the management of microbial keratitis. Ophthalmology. 1981; 88: 814-20. http://doi.org/10.1016/s01616420(81)34943-4.

35. Pepose JS, Wilhelmus KR. Divergent approaches to the management of corneal ulcers. Am J Ophthalmol. 1992; 114: 630-2. http://doi. org/10.1016/s0002-9394(14)74496-4.

36. Rietveld RP, ter Riet G, Bindels PJ et al. Predicting bacterial cause in infectious conjunctivitis: cohort study on informativeness of combinations of signs and symptoms. BMJ. 2004; 329: 206-10. http://doi.org/10.1136/bmj.38128.631319.AE.

37. Seal DV, Barrett SP, McGill JI. Aetiology and treatment of acute bacterial infection of the external eye. Br J Ophthalmol. 1982; 66: 357-60. http://doi.org/10.1136/bjo.66.6.357.

38. Saini JS, Jain AK, Kumar S et al. Neural network approach to classify infective keratitis. Curr Eye Res. 2003; 27: 111-6. http://doi. org/10.1076/ceyr.27.2.111.15949.

39. Klamann MKJ, Maier AK, Gonnermann J et al. Ocular surface temperature gradient is increased in eyes with bacterial corneal ulcers. Ophthalmic Res. 2013; 49: 52-6. http://doi.org/10.1159/000343774.

40. Kawali AA. Thermography in ocular inflammation. Indian J Radiol Imaging. 2013; 23(3): 281-3.

41. Modrzejewska A, Cieszyński Ł, Zaborski D. Imaging of Inflammatory Ocular Conditions with a Thermographic Camera. Klin Oczna. 2019; 4: 121.

42. Stroszczynski C, Hosten N, Bornfeld N et al. Choroidal Hemangioma: MR Findings and Differentiation from Uveal Melanoma. AJNR Am J Neuroradiol. 1998; 19: 1441-7.

43. Kruszewski S. Use of thermography and thermovision in medicine. Pol Przegl Radiol Med Nukl. 1971; 35(4): 441-4.

44. Wittig I, Kohlmann H, Lommatzsch PK et al. Static and dynamic infrared thermometry and thermography in malignant melanoma of the uvea and conjunctiva. Klin Monbl Augenheilkd. 1992; 201(5): 317-21. http://doi.org/10.1055/s-2008-1045909.

45. Buzug TM, Schumann S, Pfaffmann L et al. Functional infrared imaging for skin-cancer screening. Conf Proc IEEE Eng Med. Biol Soc. 2006; 1: 2766-9. http://doi.org/10.1109/IEMBS.2006.259895.

46. Iveković R, Lovrencić-Huzjan A, Mandić Z et al. Color Doppler flow imaging of ocular tumors. Croat Med J. 2000; 41(1): $72-5$.

47. Yang YC, Kent D, Fenerty CH et al. Pulsatile ocular blood flow in eyes with untreated choroidal melanoma. Eye. 1997; 11: 331-4. http:// doi.org/10.1038/eye.1997.70.

48. Olbryt M. Rola mikrośrodowiska nowotworowego w powstaniu i progresji czerniaka skóry. Postępy Hig Med Dośw. 2013 ; 67: 413-32. 
49. Clarijs R, Schalkwijk L, Ruiter DJ et al. EMAP-II expression is associated with macrophage accumulation in primary uveal melanoma. Invest Ophthalmol Vis Sci. 2003; 44: 1801-6. http://doi.org/10.1167/iovs.02-0624.

50. Richmond A, Thomas H. Purification of melanoma growth stimulatory activity. J Cell Physiol. 1986; 129: 375-384. http://doi.org/10.1002/ jcp.1041290316.

51. Lee CS, Jun IH, Kim TI et al. Expression of 12 cytokines in aqueous humour of uveal melanoma before and after combined Ruthenium-106 brachytherapy and transpupillary thermotherapy. Acta Ophthalmologica. 2012; 90(4): 314-20. http://doi.org/10.1111/j.17553768.2012.02392.x.

52. Modrzejewska A, Cieszyński Ł, Zaborski D et al. Thermography in clinical ophthalmic oncology. Arq Bras Oftalmol. 2021; 84(1): $22-30$. http://doi.org/10.5935/0004-2749.20210004.

53. Archer DB. Doyne Lecture. Responses of retinal and choroidal vessels to ionizing radiation. Eye. 1993; 7: 1-13. http://doi.org/10.1038/ eye.1993.3.

54. Konstantinidis L, Damato B. Intraocular Metastases-A Review. Asia Pac J Ophthalmol (Phila). 2017; 6(2): 208-14. http://doi.org/10.22608/ APO.201712.

55. Sodi A, Giambene B, Falaschi G et al. Ocular surface temperature in central retinal vein occlusion: preliminary data. Eur J Ophthalmol. 2007; 17(5): 755-9. http://doi.org/10.1177/112067210701700511.

56. Chandrasekar B, Rao AP, Murugesan M et al. Ocular surface temperature measurement in diabetic retinopathy. Exp Eye Res. 2021; 211: 108749. http://doi.org/10.1177/112067210901900617.

57. Sodi A, Matteoli S, Giacomelli G et al. Ocular Surface Temperature in Age-Related Macular Degeneration. J Ophthalmol. 2014; 2014: 281010. http://doi.org/10.1155/2014/281010.

58. Klamann MK, Maier AK, Gonnermann J et al. Thermography: A New Option to Monitor Filtering Bleb Function? J Glaucoma. 2015; 24(4): 272-7. http://doi.org/10.1097/IJG.0b013e31825af0ca.

Conflict of interest:

None.

Financial support:

None.

Ethics:

The content presented in the article complies with the principles of the Helsinki

Declaration, EU directives and harmonized requirements for biomedical journals. 